\title{
ADEA-ADEE Shaping the Future of Dental Education III
}

\section{The impact of scientific technologies and discoveries on oral health globally}

\author{
Irina F. Dragan DDS, MS ${ }^{1} \quad$ Muhammad Walji Ph. ${ }^{2} \quad \mid$ Marjoke Vervoorn DDS, PhD $^{3}$ | \\ Barry Quinn BDS, MSc, LDS, MRD, FDS, FFD, FHEA, FDTFEdc ${ }^{4}$ Lynn Johnson PhD ${ }^{5}$ | \\ Joan Davis PhD ${ }^{6} \quad$ Lily T. Garcia DDS, MS $^{7} \quad$ Richard W. Valachovic DMD, MPH ${ }^{8}$
}

\footnotetext{
${ }^{1}$ Tufts University School of Dental Medicine, USA

${ }^{2}$ University of Texas School of Dentistry at Houston

${ }^{3}$ Academic Centre for Dentistry Amsterdam, The Netherlands

${ }^{4}$ King's College London

${ }^{5}$ Department of Periodontics and Oral Medicine, School of Dentistry and Clinical Professor of Information, School of Information, University of Michigan, Ann Arbor, Michigan, USA

${ }^{6}$ Special Projects \& Initiatives, A.T. Still Missouri School of Dentistry \& Oral Health

${ }^{7}$ University of Nevada, School of Dental Medicine, Las Vegas

${ }^{8}$ American Dental Education Association

Correspondence

Irina F. Dragan, Assistant Professor of Periodontology, Tufts University School of Dental Medicine, USA.

Email:irina.dragan@tufts.edu
}

\begin{abstract}
The central purpose of scientific research and emerging dental health technologies is to improve care for patients and achieve health equity. The Impact of Scientific Technologies and Discoveries on Oral Health Globally workshop conducted joint American Dental Education Association (ADEA) and the Association for Dental Education in Europe (ADEE) 2019 conference, Shaping the Future of Dental Education III, highlighted innovative technologies and scientific discoveries to support personalized dental care in an academic and clinical setting. The 2019 workshop built upon the new ideas and way forward identified in the 2017 ADEE-ADEA joint American Dental Education Association (ADEA) and the Association for Dental Education in Europe (ADEE) 2019 conference, Shaping the Future of Dental Education II held in London. During the most recent workshop the approach was to explore the "Teaching Clinic of the Future". Participants applied ideas proposed by keynote speakers, Dr. Walji and Dr. Vervoorn to educational models (Logic Model) in an ideal dental education setting. It is only through this continuous improvement of our use of scientific and technological advances that dental education will be able to convey to students the cognitive skills required to continually adapt to the changes that will affect them and consequently their patients throughout their career. This workshop was a valuable experience for highlighting opportunities and challenges for all stakeholders when aiming to incorporate new technologies to facilitate patient care and students' education.
\end{abstract}

\section{K E Y W O R D S}

dental education, innovation, logic model, person-centered care, technology

\section{1 | INTRODUCTION}

The central purpose of scientific research and emerging dental health technologies is to improve care for patients and achieve health equity. The aim of this workshop was to highlight innovative technologies and scientific discoveries to support personalized dental care in an academic and clinical setting. During this "Teaching Clinic of the Future" 
TA B L E 1 Summary of dental education and patient care technologies

$\begin{array}{ll}\text { Preclinical } & \text { - Augmented reality } \\ \text { education } & \text { - Virtual reality } \\ & \text { - Haptic technology } \\ & \text { - Robot patient simulator } \\ & \text { - Integrated TEl system } \\ \text { - HDperlinked 2D/3D imaging } & \text { - Faculty evaluations via video and audio } \\ \text { - E-portfolio } \\ \text { - VR complements mannequins } \\ \text { - } 3 \mathrm{D} \text { printing simulates tissues } \\ \text { - Collaborative learning technologies } \\ \text { - Video for teaching communications }\end{array}$

\begin{tabular}{|c|c|}
\hline $\begin{array}{l}\text { "In the } \\
\text { classroom" } \\
\text { learning }\end{array}$ & $\begin{array}{l}\text { - Podcasts and webinars } \\
\text { - Software for curriculum } \\
\text { - Ananagement/mapping } \\
\text { - Delivery strategies } \\
\text { - Virtual reality } \\
\text { - Interactive e-learning } \\
\text { - Case-based } \\
\text { - Social media as an advising and motivation } \\
\text { - tool } \\
\text { - Caming } \\
\text { - Stoud Learning management system (LMS) } \\
\text { - Cross country and institutional teaching } \\
\text { - Flexibility in licture } \\
\text { - Flipped classroom } \\
\text { - Daily quizzes } \\
\text { - Online learning with embedded quizzes }\end{array}$ \\
\hline Telehealth & $\begin{array}{l}\text { - Professional versus student } \\
\text { - Variety of techniques - many untested } \\
\text { - Behavioral approaches and kills } \\
\text { - Data used for decision support, access, cpst, } \\
\text { - follow-up care } \\
\text { - Second opinion } \\
\text { - Specialty care } \\
\text { - Faculty evaluation of teaching } \\
\text { - Team teaching (horizontal and vertical) } \\
\text { - Interdisciplinary experiences including } \\
\text { - geographical } \\
\text { - Cloud electronic health record (EHR) and } \\
\text { - Sdvance data collection } \\
\text { - Consultations, diagnosis and triage } \\
\text { - Combine with mobile clinic }\end{array}$ \\
\hline Patient care & $\begin{array}{l}\text { - Videos of treatments and analysis (feedback to } \\
\text { students) } \\
\text { - Artificial intelligence that learns about } \\
\text { students (analytics) } \\
\text { - Complex scenarios } \\
\text { - 3D printing }\end{array}$ \\
\hline
\end{tabular}

(Continues)
T A B L E 1 (Continued)

- $\mathrm{CBCT}$

- Genetic sequencing

- Personalized medicine

- Big data for decision support

- Imaging, scanning, e-assisted surgical tools

- Faculty evaluations

- Team (horizontal and vertical)

- Patient perspective

- E-portfolio

- Community-based education

- Voice Operated/integrated EHRs

- Interprofessional collaboration

workshop, participants were able to apply the ideas proposed by keynote speakers, Dr. Walji and Dr. Vervoorn to educational models (Logic Model) in an ideal dental education setting.

Learning objectives:

- Discuss the differences and similarities between the concepts: "person" vs. "patient" vs. "student" -centered dental teaching care.

- Discuss opportunities and challenges to incorporate such a model for the academic, research, and practicing dental communities.

- Describe challenges for stakeholders when aiming to incorporate use of new technologies in a dental curriculum

- Identify risk factors for success when integrating technologies, how to design an implementation strategy and assess institutional outcomes: education and patient care.

\section{2 | BACKGROUND AND LITERATURE REVIEW}

Advances in health technology and scientific research are transforming healthcare in dramatic ways. Artificial intelligence, gene therapy, new drugs, new devices, 3D printed body parts, wearable medical devices are only a few advances on the horizon. The 2017 ADEE/ADEA Shaping the Future of Dental Education II conference included a workshop on science and technologies. ${ }^{1}$ Specifically, the participants looked forward ten years to 2027 and attempted to predict the new technologies that could impact patient care and dental education. Four groups of technologies were identified: preclinical education, "In the classroom" learning, telehealth and patient care. The resulting 2018 manuscript described potential new technologies and how dental educators might adapt to these new technologies and prepare students for an unpredictable future (Table 1). Participants listed the most important scientific discoveries related to dentistry. They then described strategies that could be used to incorporate that knowledge in order to enable students to think critically about future 
TA B LE 2 Summary of scientific discoveries discussion

\begin{tabular}{|c|c|}
\hline $\begin{array}{l}\text { New ideas: } \\
\text { What are the } \\
\text { most important } \\
\text { areas of new } \\
\text { scientific } \\
\text { discoveries? }\end{array}$ & $\begin{array}{l}\text { Early diagnosis and monitoring, } \\
\text { nanomedicine, informatics, salvia as a } \\
\text { diagnostic } \\
\text { - Ecology, microbiome and the biofilm, } \\
\text { understanding interactions with our } \\
\text { microbiome for early diagnosis } \\
\text { - Regenerative dentistry (soft and hard tissues) } \\
\text { - Bioactive materials: enhancing the tooth's } \\
\text { innate ability to repair }\end{array}$ \\
\hline
\end{tabular}

\begin{tabular}{|c|c|}
\hline $\begin{array}{l}\text { Way forward: } \\
\text { How do we } \\
\text { introduce these } \\
\text { new discoveries } \\
\text { to our student } \\
\text { and create } \\
\text { critical } \\
\text { thinkers? }\end{array}$ & $\begin{array}{l}\text { - Change assessment methods (embedding } \\
\text { critical thinking in assessment) } \\
\text { - Giving students a robust methodology for } \\
\text { evaluation of evidence (prepare faculties - } \\
\text { Socratic approach) } \\
\text { - Clinical treatment planning and case } \\
\text { discussion } \\
\text { - Inter-year, interprofessional and } \\
\text { intraprofessional; (peer-to-peer support and } \\
\text { librarians) } \\
\text { - Personalize (make your own soup) innovative } \\
\text { creative methods (gamification, social media, } \\
\text { etc.) }\end{array}$ \\
\hline $\begin{array}{l}\text { Examples of } \\
\text { best practices }\end{array}$ & $\begin{array}{l}\text { - Students carry out systematics reviews of the } \\
\text { literature and learn how to critically assess } \\
\text { what they read } \\
\text { - Importance of learning how to analyze bias } \\
\text { - Importance of being exposed to both good and } \\
\text { bad systematic reviews } \\
\text { - Pros and cons of meta-analyses }\end{array}$ \\
\hline
\end{tabular}

scientific discoveries. Strategies for teaching scientific information were summarized and examples of best practices were recorded. The key theme of the 2017 workshop was to encourage dental students to be critical consumers of scientific innovations (Table 2).

A historical review confirms that technological change is not only inevitable but also exponential. Consequently, instead of experiencing 100 years of progress in this century we could experience as much as 20,000 years of progress. ${ }^{2}$ As more effective ways to do things are discovered, more effective ways are needed to learn new things. Major advances in our ability to discover and convey information occur increasingly close together. ${ }^{3}$ Life in the industrialized world would not be recognized by a time traveler from the first half of the 20th century. This pattern will culminate in unimaginable scientific and technological progress throughout the 21 st century. We as dental educators need to be prepared.

\section{3 | METHODS AND WORKSHOP FORMAT}

The 2019 ADEE/ADEA Shaping the Future of Dental Education III Science and Technology workshop was structured in two parts: engaging presentations and group discussions. Throughout the workshop a Logic model to assess technologies and scientific discoveries that are shaping patient care in dental education. The first presentation described the differences and similarities between the concepts: "person" vs. "patient" vs. "student"-centered dental teaching care. The opportunities and challenges to incorporate academic, research, and practicing dental community models were described. The second presenter highlighted lessons learned from the development and implementation of new technologies. Using a futuristic approach, the presenter went on to describe the integration of technology and clinical training. Participants discussed and applied the ideas in presented by the speakers to the Logic Model of Program Evaluation assumptions, planned work and intended results). ${ }^{4}$ Faculty members, students, practitioners and corporate representatives from various countries were divided into six different teams. Working collaboratively, they compiled Logic models for various academic settings: preclinical, clinical and didactic. The larger group selected and discussed an example of the proposed Logic Model which described resources and activities needed to achieve intended results: output, outcomes and impact (Figure 1). The use of such a framework guided the discussions to a meaningful experience appreciated by all participants.

The primary mission of many academic dental institutions is to train students leading to a "student-centered" approach for delivering care. Due to a rapidly changing information landscape,${ }^{5}$ dental schools need to train and prepare future practitioners to provide person-centered care. ${ }^{6}$ Dental schools have a great opportunity to adapt and change both the didactic and clinical curriculum using technology and innovation to better serve patients.

\section{4 | WORKSHOP PRESENTATIONS}

Teaching Person-Centered Care: A Futuristic Approach. Professor Muhammad Walji, PhD.

Pioneering the Use of Technology in Dental Education: Lessons Learned". Marjoke Vervoorn, DDS, PhD

\section{1 | Workshop presenters view}

The current oral healthcare delivery system is broken. Many individuals lack access to care and those who are able to find dental care, may not receive care based on the best scientific evidence. Care is rarely designed to fit patients' needs or individual circumstances. There is also a lack of data to appropriately measure the quality of oral healthcare which is critical for driving improvements. Dental education traditionally prepares students thoroughly for treating patients under 


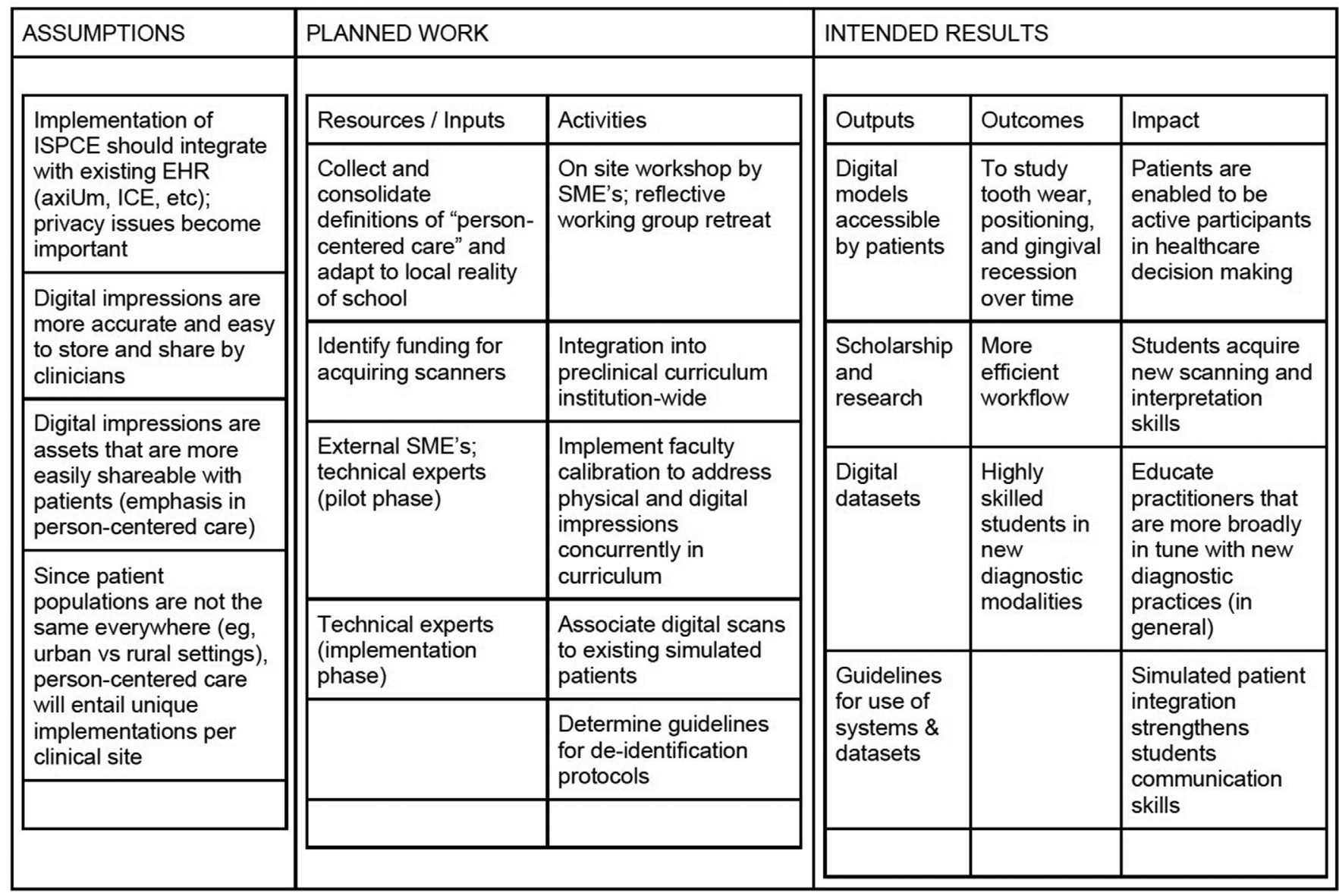

F I G U R E 1 Application of the Logic Model for a case: Implementation of intraoral scanners in preclinical education

supervision of dentist teachers. For this, students learn to manage instruments and dental procedures on phantom heads with artificial jaws and teeth. Only limited time is dedicated to clinical problem solving in preclinical training, as this is heavily dependent on availability of extracted teeth with those problems. Mostly, the development of the clinical problem-solving competence takes place in the clinics while treating patients. Though students manage the tools to solve those problems, the actual treatment is almost an experiment in itself as the clinical situation of every patient is unique.

In academic dental institutions, the delivery system is also setup around the student dental provider. Students require practice and experience in performing certain procedures and are assigned patients based on these needs. Some patients who are deemed too complex for treatment by students may be turned away. In this training environment, measures must be in place to ensure that dental patients at our academic dental institutions should receive high quality care. Quality is defined as "the degree to which health services for individuals and populations increase the likelihood of desired health outcomes and are consistent with current professional knowledge. ${ }^{7 "}$ The first step is to measure the quality of care at our institutions.
The National Academy of Science suggests that care should be 1) patient centered, 2) safe, 3) effective, 4) timely, 5) efficient, and 6) equitable. ${ }^{7}$ With the increased use of electronic health records (EHRs), it now feasible to accurately measure these components. For example, EHRs can be mined to find cases of wrong tooth extractions and other instances of harm associated with dental care. ${ }^{8}$ One can also quantify the degree to which evidence-based practices are occurring such as the provision of sealants to children to help prevent dental caries. ${ }^{9}$ Additionally, one can also determine how quickly patient's receive care and if the care delivered is equitably.

Measurement is only the first step. One should next share and compare existing data with other similar institutions. After the initial analysis is completed, academic institutions can work together to share both data and processes in a common quest for improvement. The Big Mouth Dental Data Repository ${ }^{10}$ is an example of platform used by some academic dental institutions to share data and compare the quality of care. Well-established frameworks such as the Institute for Health Innovation care Improvement (IHI) Model for Improvement which includes a set of questions that drive the improvement activity and the Plan-Do-Study-Act (PDSA) 
cycle that helps to test and implement changes. ${ }^{11}$ Instead of relying on a top-down administrator heavy approach for finding solutions, academic institutions may use approaches such as "Design Thinking ${ }^{12}$ "which was originally popularized by the design firm IDEO to design functional and aesthetic products. The same approach can be applied to designing a person-centered academic dental clinic.

New technologies enable to copy the real world including the unique clinical problem in a virtual reality environment. ${ }^{13}$ Preparing in such an environment before actually performing the treatment in reality, improves the preparation of the students and makes the actual treatment more predictable. This can be practiced several times, if necessary by the student in the safe environment.

Though it seems obvious that such use of such technology increases the quality of care, it is not naturally accepted by all the stakeholders within the clinical environment. It is considered a futuristic approach instead of daily practice. Including new technology in an existing environment - even though the added value seems obvious - needs a careful step by step approach. Creating evidence during those steps supports the use of the innovation in an academic environment aiming for evidence-based practice. ${ }^{14}$

To prepare for such a step by step approach, various models can be applied, for instance the Logic Model of Program Evaluation. ${ }^{4}$ Application of the Logic Model during the workshop of the ADEE/ADEA meeting in Brescia May 2019 resulted in better understanding of the added value of precise preparation for change. Going through the structured steps of the model resulted in a rehearsal of an intended change, allowing to identify and eliminate obstacles prior to the implementation of the change. Also the stepwise approach provides the opportunity to let the implementation of new technology go hand in hand with quality assurance processes, by monitoring the outcomes of each step and include this in measures aiming to improve the quality standards. ${ }^{15}$ This way, change is managed controlling the process and protecting it through including it in the quality assurance process of the institute.

\section{5 | DISCUSSION}

Technology in the healthcare sector has effected, and will continue to effect, massive impacts on nearly all processes and practices. The educational and cultural implications of these changes are so large as to be almost incomprehensible. Thus, it is critical that across the globe, dental educators continue to examine scientific and technology advances and continue to improve the strategies used to incorporate these advances into our instruction.

Within the next decade, technology and artificial intelligence or machine learning will impact the digitisation of health care records and the patients' journey through the health care system. ${ }^{16}$ Big data will streamline the journey from a "patient" to a "person" and continuous recording of data will help stop or at least delay some persons becoming patients. Computerised or digital records will ease the workflow and retrieval of data, increasing productivity and efficiency of healthcare systems. Disease patterns and clusters of diseases within populations will be more easily recognised, predicting epidemics, avoiding preventable deaths, improving quality of life and identifying most effective treatments. ${ }^{17}$

Patients with remote access to health care will be able to tele-communicate over $5 \mathrm{G}$ networks with smart phones for initial consultations and diagnosis with automatic teleassistants, who will be able to advise and triage patients appropriately. Automatic assistants will eventually be able to counsel, educate and support with custom developed healthcare software. ${ }^{18}$ These new artificial intelligence systems might be able to free up the doctor's time, affording more time to be given to patients with greater priorities. The initial screening and suggested diagnostic tests may reduce medical errors in the future but this will be highly dependent on the accuracy of the screening software. A challenge will be with patients having self-access to this software and potentially misdiagnosing or being overly concerned when they do not need to be.

Mobile devices already offer the ability to monitor cardiac rhythm, heart rate and activity with "nudge" reminders to change behaviour. ${ }^{19}$ In the near future, electric toothbrushes will be able to monitor heart rate, and sample saliva for glucose and other biomarkers of disease. ${ }^{20}$ Challenges will be in storing big data, ensuring its secure and making sure that permission to use or share is explicitly given. ${ }^{21}$

It is only through this continuous improvement of our use of scientific and technological advances that dental education will be able to convey to students the cognitive skills required to continually adapt to the changes that will affect them and consequently their patients throughout their career.

\section{6 | RECOMMENDATIONS}

In summary, academic dental institutions have the potential to transform into dynamic learning health systems focused on delivering the right care to the right patient at the right time. $^{22,23}$ This vision requires a change from a studentcentered approach to one that is person-centered and supported by an effective informatics infrastructure allowing for self-reflection and learning.

Applying a structured approach for use of technology may make the future present. In the specific example of using new technology to add a safe virtual reality learning environment to the clinical training environment, education and care both benefit as better preparation for a specific dental treatment increases the predictability of the treatment outcome and thus the safety of all stakeholders in the clinic. These 
stakeholders include the patient, the student and the teacher, the latter being familiar with the competence of the student prior to supervising them while they perform the specific treatment to a patient.

\section{7 | CONCLUSIONS}

This workshop was a valuable experience for highlighting opportunities and challenges for all stakeholders when aiming to incorporate new technologies to facilitate patient care and students' education.

New dentists of the future need to be educated with in the wider healthcare team, and involved more with general health, its maintenance and disease prevention. New simulations with mixed reality will allow students to interact with virtual patients, formulating diagnoses and surgically intervening when required. These new technologies will allow personalized learning plans with different students progressing at different rates through the program. Reflection and self-feedback can be encouraged with less reliance on expert teachers.

The potential is limitless, but the cost and speed of developing new technologies working within the legal restraints of some jurisdictions may hinder important technological breakthrough.

\section{REFERENCES}

1. Dragan I, Dalessandri D, Johnson LA, Tucker A, Walmsley AD Impact of scientific and technological advances. Eur J Dent Educ. 2018;22(Suppl 1):17-20.

2. Kurzweil R. The Law of Accelerating Returns. March 7, 2001.

3. Kurzweil R. The Age of Spiritual Machines. Viking, 1999.

4. Cooksy LJ, Gill P, Kelly A. The program logic model as an integrative framework for a multimethod evaluation. Evaluation and Program Planning. 2001;24:119-128.

5. Palatta AM, Kassebaum DK, Gadbury-Amyot CC, et al. Change is here: aDEA CCI 2.0-a learning community for the advancement of dental education. J Dent Educ. 2017;81(6):640-648.

6. Walji MF, Karimbux NY, Spielman AI. Person-centered care: opportunities and challenges for academic dental institutions and programs. J Dent Educ. 2017;81(11):1265-1272.

7. Corrigan JM. Crossing the quality chasm. Building a better delivery system. 2005.

8. Kalenderian E, Obadan-Udoh E, Yansane A, et al. Feasibility of electronic health record-based triggers in detecting dental adverse events. Appl Clin Inform. 2018;9(3):646-653.

9. Kumar SV, Bangar S, Neumann A, et al. Assessing the validity of existing dental sealant quality measures. J Amer Den Assoc. 2018;149(9):756-764. e751.

10. Walji MF, Kalenderian E, Stark PC, et al. BigMouth: a multiinstitutional dental data repository. J Am Med Inform Assoc. 2014;21(6):1136-1140
11. Institute for Healthcare Improvement. Science of Improvement: How to Improve. Accessed 23 October 2017 at: http://www.ihi. org/resources/Pages/HowtoImprove/ScienceofImprovementHowto Improve.aspx.

12. Emanuel L, Berwick D, Conway J, et al. What exactly is patient safety? 2008.

13. Serrano CM, Wesselink PR, Vervoorn JM. Real patients in virtual reality: the link between phantom heads and clinical dentistry. Ned Tijdschr Tandheelkd. 2018;125:263-267.

14. de Boer IR, Bakker DR, Serrano CM, Koopman P, Wesselink PR, Vervoorn JM. Innovation in dental education: The on-the-Fly approach to simultaneous development, implementation and evidence collection. Eur J Dent Educ. 2018;22:215-222.

15. Jones ML, Hobson RS, Plasschaert AJ, et al. Quality assurance and benchmarking: an approach for European dental schools. Eur J Dent Educ. 2007;11:137-143.

16. Chawla NV, Davis DA. Bringing big data to personalized healthcare: A patient-centered framework. J Gen Internal Med. 2013;28(Suppl 3):660-665.

17. Chen M, Hao Y, Hwang K, Wang L, Wang L. Disease prediction by machine learning over big data from healthcare communities. IEEE Access. 2017;5:8869-8879.

18. Jiang F, Jiang Y, Zhi H, Dong Y, Li H, Ma S. Artificial intelligence in healthcare: past, present and future. Stroke Vascular Neuro. 2017:230-243.

19. Malon RS, Sadir S, Balakrishnan M, Córcoles EP, Saliva-Based Biosensors: Noninvasive Monitoring Tool for Clinical Diagnostics. BioMed Research International. 2014.

20. Roski J, Bo-Linn GW, Andrews TA. Creating value in health care through big data: Opportunities and policy implications. Health Affairs. 2014;7:1115-1122.

21. Thaler RH, Sunstein C. Nudge: Improving Decisions about Health, Wealth, and Happiness. Yale University Press; 2008.

22. Olsen LA, Aisner D, McGinnis JM, eds. The Learning Healthcare System: Workshop Summary. Washington (DC): National Academies Press (US) National Academy of Sciences; 2007. Institute of Medicine Roundtable on Evidence-Based M. The National Academies Collection: Reports funded by National Institutes of Health.

23. Card SK, Moran TP, Newell A. The Psychology of HumanComputer Interaction. London: Lawrence Erbaum Associates; 1983.

How to cite this article: Dragan IF, Walji M, Vervoorn M, et al. ADEA-ADEE Shaping the Future of Dental Education III: The impact of scientific technologies and discoveries on oral health globally. J Dent Educ. 2020;84:111-116. https://doi.org/10.1002/jdd.12027 